\title{
The Role of Information Technology in Mediating the Effect of Medical Resources on Hospital Clinical Performance
}

\author{
Daniel Kartawiguna ${ }^{1}$, Harjanto Prabowo ${ }^{2}$, Tjibeng Jap ${ }^{3}$ \\ ${ }^{1}$ Bina Nusantara University, Indonesia, daniel@ binus.ac.id \\ 2 Bina Nusantara University, Indonesia, harprabowo@binus.edu \\ ${ }^{3}$ Universitas Tarumanagara, Indonesia, t.jap@untar.ac.id
}

\begin{abstract}
Healthcare is an extremely important sector of theeconomy, as it involves the improvement and maintenance of human health. Despite its importance, many healthcare challenges exist, as a result of increased costs that are not associated with the quality of healthcare. Consequently, the primary purpose of this investigation is to examine the role of information technology (IT) in mediating the effect of medical resources on clinical performance. Medical resources were measured using human resource and medical technology dimensions. The research capability is referred to as IT and knowledge management capabilities. An empirical survey was conducted at 34 accredited hospitals located in the Special Capital Region of Jakarta. A multivariate statistical analysis, applying structural equation modeling - partial least squares, revealed that the role of IT capabilities were statistically significant in mediating the effect of medical human resources on clinical performance. No significant direct effect of medical resources on clinical performance was observed. The results imply the significant role of IT capabilities in healthcare industries, particularly in hospitals in Jakarta, Indonesia.
\end{abstract}

Key words : Medical human resources, Medical technology, Information technology capability, Knowledge management capability, Clinical performance.

\section{INTRODUCTION}

The importance of human healthcare and the impact of increasing healthcare service costs on the economy has resulted in many research investigations being conducted [1] OECD data has revealed that China and India have experienced the highest growth in healthcare spending, with an average of $11 \%$ and $8.9 \%$ AAGR (Average annual per capita growth) annually, respectively. Healthcare spending is expected to increase on an annual basis under conditions of good economic growth [2]. That being said, an increase in healthcare expenditures does not necessarily reflect an increase in healthcare quality [3].

In Indonesia, the cost of healthcare treatment at government hospitals can be 3 times more expensive than that of private hospitals in Malaysia [4]. In addition, some patients believe that the healthcare service quality, security, and medical supervision in Indonesia is not guaranteed [5]. Therefore, many Indonesian patients are more confident in the abilities of foreign medical organizations [6] (e.g., Singapore, Malaysia, Thailand).

In 2006, 350 thousand Indonesian patients went abroad for healthcare-related treatment. In 2015, this number soared to 600 thousand patients. Also, in 2015, the total expenditures of Indonesian patients abroad reached US $\$ 1.4$ billion (i.e., IDR 18.2 trillion). This is because Indonesian patients are more confident with healthcare services abroad, as they are perceived to offer a better service quality, security and supervision [7].

Information technology (IT) can be used to improve healthcare services [8] in relation to quality and cost efficiency. Computer technology has already revolutionized many industries (e.g., telecommunications, finance, banking, air transportation) [9]. However, to date, it has had an insignificant impact on healthcare services [10].

Several scholars report slow progress on the part of healthcare providers to understand IT, to exploit IT into their practical function, and to incorporate IT effectively into the work environment [11] [12] [13]. Even in the United States (US), the adoption of IT systems in the healthcare industry has only been only modest, as compared to that of other industries [14].

The evolution of information systems (IS)/IT in a business and organizational context has been rapid [15], but also erratic. It has improved back-office efficiency and created new strategic opportunities and business models [16]. Many studies have discussed the strategic role of IT in organizational performance [15] [17], including hospital business performance [18]. However, no significant research has been conducted on the relevance of IT's strategic role in improving clinical performance. Clinical performance information is useful at various levels of the organization for quality improvements [19].

The major purpose of this paper is to examine the role of IT in mediating the effect of medical resources on clinical performance. It also aims to examine the direct effect of medical resources on clinical performance. 


\section{LITERATURE REVIEW}

Penrose (1959) identified that company resources are an important factor of a company's success. However, it was not until the 1980s that a resource-based view (RBV) of a company began to emerge [20] [21]. A RBV can become a Resource-based Theory (RBT) [22]. This RBV states that the company's internal factors, in terms of resources and capabilities, will determine the company's profitability. The RBT assumes that the resources needed to understand, select, and implement strategies are heterogeneously distributed across the enterprise and that these firm differences remain stable over time [23]. Thus, the RBV on firms has been affirmed as an important framework and serves as a basis for explaining and predicting the competitive advantage and performance of a company [20].

The proponents of the RBV generally tend to define resources widely (e.g., assets, knowledge, capabilities, organizational processes). However, some researchers [24] [25] distinguish between resources and capabilities. Resources are defined as the basic unit of analysis. Firms create a competitive advantage by assembling the resources that work together to create organizational capabilities. Firm resources include all assets, capabilities, organizational processes, firm attributes, information, and knowledge, controlled by a firm that enables the firm to conceive of, and implement, strategies [25].

Resources are tangible and intangible assets that companies use to develop and implement strategies [26]. The word "resource" refers to something an organization can use to achieve its goals [20]. Barney and Hesterly (2015) discussed four major resource categories: physical, financial, human, and organizational [27]. Resources and capabilities are the two central constructs in RBT [20]. The term "capability" refers to the organizational capability to assemble, integrate, and use valuable resources, usually in combination at the same time [28].

Grant (2016) described the hierarchy of organizational capabilities, in which special abilities are integrated into broader functional capabilities (e.g., marketing, manufacturing, IT) [29]. Functional capabilities, in turn, integrate to form cross-functional capabilities (e.g., new product development capabilities, customer support capabilities). Capability is a subset of corporate resources, representing specific resources embedded in organizational non-transferable companies whose purpose is to increase the productivity of other resources owned by the company [30].

According to Pavia (2002), clinical performance can be influenced by 4 factors mentioned in RBV: 1) processes, 2) human resources, 3) systems and infrastructure, and 4) knowledge [31]. The most important healthcare system inputs that impact the performance and benefits of healthcare systems include human resources, physical capital, and consumables (e.g., drugs, prosthesis, disposable medical equipment) [32]. We select resources, as a variable in this study, and medical human resources and medical technology resources as the dimension. Medical technology resources include medical equipment and medical consumables.

Medical human resources are an important dimension of resources, because RBV argued that the functioning of human resources plays an important role in corporate performance [22]. This research will implement this concept on the clinical environment. The clinical process is excluded, because it is outside the realm of management science.

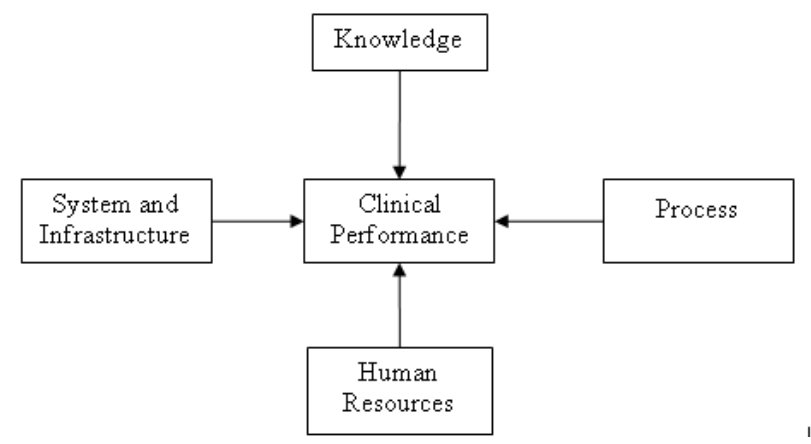

Figure 1: Factors that affect hospital clinical performance (Pavia, 2002)

IS/IT has the potential to be a source of excellence in the management of information systems. Organizations must develop effective capabilities in IT implementation to gain a competitive advantage for the organization [33]. Therefore, IS/IT capability is the dimension of the capability variable in this investigation.

The linkage between IT capability and company performance has been investigated by Bharadwaj (2000) and Santhanam \& Hartono (2003) [33] [34]. The results of a study by Bharadwaj (2000) illustrate that firms with a high IT capability tend to outperform control sample companies on various measures of profit and cost-based performance [33]. Companies that succeed in creating superior IT capabilities enjoy superior financial performance by strengthening corporate earnings and/or reducing corporate costs. Similar research has also yielded results stating that companies that succeed in creating superior IT capabilities enjoy superior financial performance by strengthening corporate earnings and/or reducing corporate costs [34]. However, Chae, Koh, \& Prybutok (2014) provided analytical results that did not show a significant relationship between IT capability and firm performance [35].

Pavia (2002) stated that knowledge can affect clinical performance. The source of the knowledge is the most valuable company resource for operating a business [31]. The organization's KM (knowledge management) capabilities directly affect the ability to innovate, capture business opportunities, respond to dynamic environments, and coordinate both external and internal sources. They also affect the performance of the organization [36]. Therefore, companies must continue improving their KM capability to improve their organizational performance [33]. Enterprise 
$\mathrm{KM}$ capability is a crucial factor affecting the performance of corporations [37]. Hence, KM capabilities have a close relationship with organizational knowledge and human resources.

As Porter \& Teisberg (2004) argue, the difference in the quality of healthcare services occurring over a lengthy period, due to the dissemination of the best healthcare practices, is very slow [38]. The KM capabilities supported by the IS/ IT capabilities are essential in addressing this problem. Tseng \& Lee (2014) examined how a company can effectively apply KM capabilities and develop unique dynamic capabilities to provide a rapid response to a dynamic environment that has become an urgent need [39]. The results illustrate that a dynamic capability is an important organizational intermediary mechanism through which the benefits of the KM capability are converted into performance effects at the enterprise level. That is, the KM capability improves the dynamic capabilities of the organization. While dynamic capabilities, in turn, improve organizational performance and provide a competitive advantage.

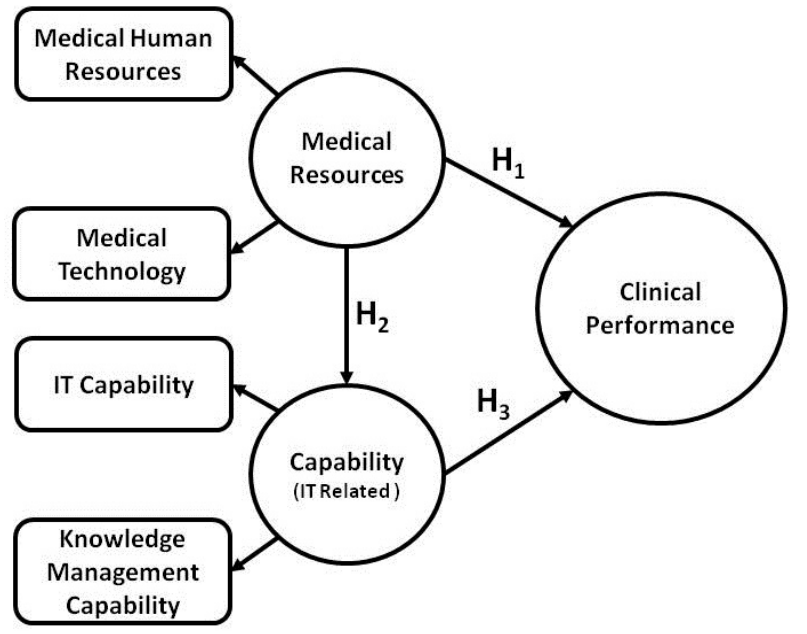

Figure 2: Research Model.

Ting-Peng, You, \& Chih-Chung (2010) compiled previous research that adopted an RBV to examine whether IT and organizational resources have a significant effect on company performance [25]. Their results revealed that the mediated model implies that the organization's capability is as a mediator between the organization's resources and the company's performance. The mediated model can also explain the value of IT better than the direct influence model, without going through an organizational capability. They also discovered that technological resources can improve performance efficiency but may not directly improve financial performance. Internal capabilities were also found to affect performance, while external capabilities affect financial performance.

In this investigation, we examined the direct relationship between capability with performance and resources with performance. In addition, we examined the relationship between resources and performance through capability. Our three research hypotheses were as follows:
H1: There is a significant direct effect of medical resources on clinical performance.

$\mathrm{H} 2$ : There is a significant direct effect of medical resources on capability (i.e., IS/IT capability and KM capability).

H3: There is a significant direct effect of capability (i.e., IS/IT capability and KM capability) on clinical performance.

\section{METHODS}

Data was collected via a 41-question survey. All questions were ranked on a Likert scale from 1 (strongly disagree) to 6 (strongly agree). The collected data was analyzed using Structural Equation Modeling. A Partial Least Squares was used to verify the research analysis. The descriptive research aims to obtain insights about the IS/IT capabilities, KM capabilities, medical human resources, medical technology resources, and clinical performance. The verification research aims to determine the relationship among the variables through hypothesis testing. All data were collected at accredited hospitals in the Special Capital Region of Jakarta.

The medical resources dimension includes medical human resources and medical technology resources. Medical human resources were measured by 4 indicators: knowledge [SDM1], commitment [SDM4], motivation [SDM5], and collaboration [SDM6]. Medical technology resources were measured by 4 indicators: adoption of new medical procedure [TM1], new technology on diagnostic [TM2], new medicine [TM3], and new medical equipment [TM4]. The capability in this research is referred to as IT and knowledge management capabilities. The IS/IT capability was measured through 15 indicators [ITC02...ITC18], asking about IT infrastructure, IT integration, IT alignment, and IT management skills. The KM capability was measured through 14 valid indicators [KMC02...KMC16], asking about knowledge acquisition, conversion, integration, application and protection. Clinical performance was measured by 4 indicators: average length of stay [CP2], readmission rate [CP3], nosocomial infection [CP4], and adverse event [CP5].

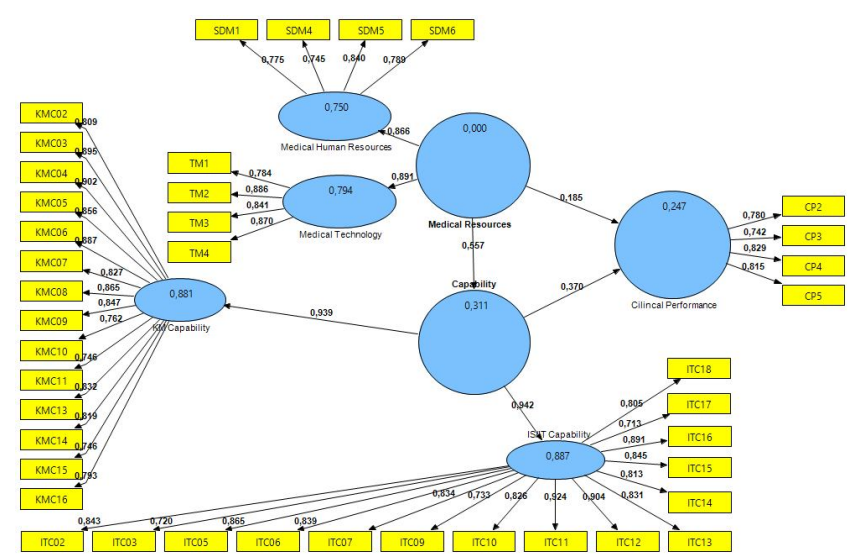

Figure 3: Measurement Model.

Purposive sampling was used to select the hospitals. This sampling method was chosen to obtain the hospital 
population. The hospitals chosen for samples had already implemented the hospital information system, based on their accreditation status from the Indonesian Commission for Hospital Accreditation (ICHA) or Joint Commission International (JCI).

The respondents were top-level management from accredited hospitals in the Special Capital Region of the Jakarta area. In total, 76 questionnaires were distributed by hand to all accredited hospitals in the Special Capital Region of Jakarta area, while 34 questionnaires were completed, for a response rate of $45 \%$. Accredited hospitals in Jakarta were selected as the population in this study, with factual consideration of hospitals in Jakarta being referral hospitals from all over Indonesia.

A Partial Least Squares Structural Equation Model (PLS-SEM) was used to analyze the data, due to the small sample size. PLS-SEM, also known as PLS path modeling, has been used to develop theories in exploratory research [40]. PLS is suitable for non-probabilistic sampling (e.g., purposive sampling), which was implemented in this investigations.

\section{RESULTS AND DISCUSSIONS}

Figure 3 presents the structural or inner model. SmartPLS 2.0 M3 software was used to import the indicator data from the questionnaire to the measurement models. The validity of the construct indicator was tested, based on the loading factor $\geq 0.7$. All indicators with a loading factor $<0.7$ were eliminated. A loading factor that was greater than 0.7 was selected, based on the rule of thumb for assessing convergent validity for confirmatory research.

Table 1 presents the results of the measurement model analysis. All constructs with a reflective indicator had AVE (average variance extracted) and communality values above 0.50 . Consequently, the convergent validity requirements were met. Furthermore, the Cronbach's Alpha and Composite Reliability value for all constructs were above 0.70 . Hence, it can be concluded that all construct indicators are reliable and pass the reliability test [39].

Table 1: Measurement Model Quality Criteria.

\begin{tabular}{lcccc}
\hline \multicolumn{1}{c}{$\begin{array}{c}\text { Construct } \\
\text { Dimension }\end{array}$} & $\begin{array}{c}\text { Number } \\
\text { of } \\
\text { Indicators }\end{array}$ & AVE & $\begin{array}{c}\text { Composite } \\
\text { Reliability }\end{array}$ & $\begin{array}{c}\text { Croubach's } \\
\text { Alpha }\end{array}$ \\
\hline $\begin{array}{l}\text { Medical Resources } \\
\text { Medical Human } \\
\text { Resources }\end{array}$ & - & 0.515 & 0.894 & 0.864 \\
\hline $\begin{array}{l}\text { Medical } \\
\text { Technology }\end{array}$ & 4 & 0.621 & 0.867 & 0.796 \\
\hline $\begin{array}{l}\text { IT Related } \\
\text { Capability }\end{array}$ & - & 0.716 & 0.910 & 0.867 \\
\hline $\begin{array}{l}\text { IT Capabiiky } \\
\text { KM Capabihy }\end{array}$ & 15 & 0.604 & 0.978 & 0.976 \\
\hline $\begin{array}{l}\text { Cinical } \\
\text { Performance }\end{array}$ & 14 & 0.687 & 0.968 & 0.965 \\
\hline
\end{tabular}

The results of the structural model analysis are presented in Table 2. The Goodness-of-Fit (GoF) value is 0.403 and the
Q-square $(\mathrm{Q} 2)$ predictive relevance value was 0.158 , which indicates that the model has predictive relevance.

Table 2: Structural (Inner) Model Analysis

\begin{tabular}{|c|c|c|c|c|c|}
\hline Construct & $\begin{array}{c}\mathbf{R} \\
\text { Square }\end{array}$ & Communality & Redundancy & GoF & $\begin{array}{l}\text { Q-square } \\
\text { predictive } \\
\text { relev ance }\end{array}$ \\
\hline $\begin{array}{l}\text { Medical } \\
\text { Resources }\end{array}$ & - & 0.515 & & 0.403 & 0.158 \\
\hline Capability & 0.310 & 0.605 & 0.183 & & \\
\hline $\begin{array}{l}\text { Cinical } \\
\text { Performance }\end{array}$ & 0.247 & 0.628 & 0.132 & & \\
\hline
\end{tabular}

The hypothesis testing was conducted by comparing the T-statistic in Table 3 with the values in the t-table.

Table 3: Inner Model T-Statistic.

\begin{tabular}{lllcccc}
\hline Construct & Capability & $\begin{array}{c}\text { Clinical } \\
\text { Performance }\end{array}$ & $\begin{array}{c}\text { IT } \\
\text { Capability }\end{array}$ & $\begin{array}{c}\text { KM } \\
\text { Capability }\end{array}$ & $\begin{array}{c}\text { Medical } \\
\text { Human } \\
\text { Resources }\end{array}$ & $\begin{array}{c}\text { Medical } \\
\text { Technology }\end{array}$ \\
\hline Capability & & $\mathbf{2 . 0 8 7 *}$ & 51.705 & 60.004 & & \\
\hline $\begin{array}{l}\text { Medical } \\
\text { Resources }\end{array}$ & $\mathbf{4 . 3 4 0 *}^{*}$ & $\mathbf{0 . 8 9 0}$ & & & 13.238 & 18.634 \\
\hline$* p=0.05$ & & & & & &
\end{tabular}

Table 3 illustrates that the influence of the medical resources on clinical performance was not significant (t-statistic $=0.890)$. Because the $\mathrm{t}$-statistic score was less than 1.96 (t-table at significance level $\alpha=0.05$ ), the $\mathrm{H} 1$ hypothesis was not supported. Medical resources, which consist of medical human resources and medical technology, do not significantly influence clinical performance.

The influence of medical resources on capability was significant $(\mathrm{T}$-statistic $=4.340)$. Since the $\mathrm{T}$-statistic score was greater than 1.96 (t-table at significance level $\alpha=0.05$ ), the $\mathrm{H} 2$ hypothesis was supported. Medical resources, which consist of medical human resources and medical technology, have a considerable influence on capability.

The capability in this research consists of the IS/IT capability and the knowledge management capability. The influence of capability on clinical performance was significant $(\mathrm{t}$-statistic score $=2.088)$. Because the $\mathrm{t}$-statistic score was greater than 1.96 (t-table at significance level $\alpha=$ 0.05), the H3 hypothesis was supported. The IT related capability, which consists of the IS/IT capability and knowledge management capability, has a considerable influence on hospital clinical performance.

The role of organizational capability is significant in mediating the effect of medical resources on clinical performance. Therefore, the mediated model shows that the organization's capability, as a mediator between medical resources and hospital clinical performance, is a model that can explain the value of IT better than a direct effects model..

\section{CONCLUSION}

Overall, the findings of this investigation have illustrated that the RBT can be implemented in a clinical environment, such as a hospital. The IT capability and knowledge management capability play a significant role in the improvement of clinical performance. Medical resources 
alone are not significant enough to affect clinical performance, but medical resources do have a significant effect on the capability. Therefore, the mediated model shows that the organization's capability, as a mediator between the organization's resources and the company's performance, is a model that can explain the role of IT better than the direct influence model. This finding supports the previous findings that emphasized the importance of the organizational capability as a mediator [25].

The results of the hypothesis test are empirical evidence of RBT, which is usually implemented in business, but is also applicable in hospital services. The IS/IT capability and knowledge management capability play a significant role in hospital clinical performance. Consequently, it is recommended that hospital management pay attention to the enhancement of organizational capabilities related to IS/IT capabilities and knowledge management capabilities in their strategic planning as managerial implications of this research. To support this result, we recommend the government to provide incentives to hospitals that have an IS/IT capability improvement program in their strategic planning, considering that an IT implementation requires a substantial financial investment.

\section{REFERENCES}

1. Fichman. R. G., Kohli, R., \& Krishnan, R. (2011). The Role of Information Systems in Healthcare: Current Research and Future Trends. Information Systems Research, 22(3), 419-428. doi:10.1287/isre.1110.0382

2. OECD. (2015). Focus on Health Spending 2015: OECD Health Statistics 2015. Organisation for Economic Co-operation and Development (OECD). Retrieved from http://www.oecd.org/health/health-systems/Focus-Healt h-Spending-2015.pdf

3. Timsina, P., El-Gayar, O., \& Nawar, N. (2014). Information Technology for Evidence Based Medicine: Status and Future Direction. Savannah: Twentieth Americas Conference on Information Systems, 2014.

4. Deny, S. (2014, 06 18:42). Ini Alasan Masyarakat RI Memilih Pengobatan ke Luar Negeri. Retrieved from Liputan 6: http://bisnis.liputan6.com/read/2068661/ini-alasan-mas yarakat-ri-memilih-pengobatan-ke-luar-negeri

5. tipsindonesia. (2015, 01 06). Kenapa Memilih Berobat ke Luar Negeri? Retrieved from http://tipsindonesia.com/:

http://tipsindonesia.com/kenapa-memilih-berobat-ke-lu ar-negeri/

6. Nainggolan, S. Y. (2016, March 30). Ini yang Membuat Orang Indonesia Lebih Suka Berobat ke Luar Negeri. Retrieved September 23, 2016, from Metro TV News: http://rona.metrotvnews.com/kesehatan/zNP23OXk-iniyang-membuat-orang-indonesia-lebih-suka-berobat-ke-1 uar-negeri

7. Asyhad, M. H., \& Purba, T. A. (2017, Juni 12). Inilah Alasan Kenapa Orang Indonesia Lebih Suka Berobat ke Luar Negeri Dibanding di Negara Sendiri. Retrieved from Intisari Onlline: http://intisari.grid.id/index.php/Wellness/Fitness-AndHealth/Inilah-Alasan-Kenapa-Orang-Indonesia-Lebih-S uka-Berobat-Ke-Luar-Negeri-Dibanding-Di-Negara-Se ndiri?page $=$ all

8. Hemmat, M., Ayatollahi, H., Maleki, M. R., \& Saghafi, F. (2017. Future Research in Health Information Technology: A Review. Perspectives in Health Information Management, 14(Winter), 1-19.

9. Tambe, P., \& Hitt, L. M. (2012). The Productivity of Information Technology Investments: New Evidence from IT Labor Data. Information Systems Research, 23(3-part-1), 599-617. https://doi.org/10.1287/isre.1110.0398

10. Khatri, N. (2006). Building IT Capability in Health-care Organizations. Health Services Management Research, 19(2), 73-79. https://doi.org/10.1258/095148406776829095

11. Shortliffe, E. H., \& Blois, M. S. (2006.) The Computer Meets Medicine and Biology: Emergence of a Discipline. In E. H. Shortliffe, \& J. J. Cimino, Biomedical Informatics: Computer Application in Health Care and Biomedicine (p. 4). New York: Springer Science+Business Media, LLC.

12. Seblega, B. K., Zhang, N. J., Wan, T. T., Unruh, L. Y., \& Miller, A. (2015). Health Information Technology Adoption: Effects on Patient Safety and Quality of Care. International Journal of Healthcare Technology and Management, 15(1), 31-48. https://doi.org/10.1504/IJHTM.2015.070519

13. Sari, M. M., Sanjaya, G. Y., \& Meliala, A. (2016). Evaluasi Sistem Informasi Manajemen Rumah Sakit (SIMRS) dengan Kerangka HOT-FIT. 2016 Seminar Nasional Sistem Informasi Indonesia. Surabaya.

14. DesRoches, C. M., Campbell, E. G., Vogeli, C., Zheng, J., Rao, S. R., Shields, A. E., \& Jha, A. K. (2010). Electronic Health Records: Limited Successes Suggest More Targeted Uses. Health Affairs, 29(4), 639-646.

15. Melville, N., Kraemer, K., \& Gurbaxani, V. (2004). Review: Information Technology and Organizational Performance: An Integrative Model of IT Business Value. MIS Quarterly, 28(2), 283-322. https://doi.org/10.2307/25148636

16. Peppard, J., \& Ward, J. (2016). The Strategic Management of Information Systems, Building a Digital Strategy (4th ed.). Hoboken, NJ: Wiley.

17. Devece, C., Palacios-Marqués, D., Galindo-Martín, M. Á., \& Llopis-Albert, C. (2017). Information Systems Strategy and Its Relationship with Innovation Differentiation and Organizational Performance. Information Systems Management, 34(3), 250-264.

18. Arvanitis, S., \& Loukis, E. N. (2016). Investigating the Effects of ICT on Innovation and Performance of European Hospitals: An Exploratory Study. The European Journal of Health Economics : HEPAC, 17(4), 403-418. doi:10.1007/s10198-015-0686-9 
19. Schmidt, E. M., Krahn, D. D., McGuire, M. H., Tavakoli, S., Wright, D. M., Solares, H. E., . . Trafton, J. (2017). Using Organizational and Clinical Performance Data to Increase the Value of Mental Health Care. Psychological services, 14(1), 13-22.

20. Kozlenkova, I. V., Samaha, S. A., \& Palmatier, R. W. (2014). Resource-based Theory in Marketing. Journal of the Academy of Marketing Science, 42(1), 1-21. https://doi.org/10.1007/s11747-013-0336-7

21. Penrose, E. T. (1959). The theory of the growth of the firm. New York: John Wiley.

22. Ahmed, A., \& Othman, I. B. (2017). Relationship Between Organizational Resources and Organizational Performance: A Conceptualize Mediation Study. European Online Journal of Natural and Social Sciences, 6(1), 10-27.

23. Barney, J. B. (1991). Firm Resources and Sustained Competitive Advantage. Journal of Management, 17(1), 99-120.

24. Grant, R. M. (1991). The Resource-Based Theory of Competitive Advantage: Implications for Strategy Formulation. California Management Review, 33(3), 114-135.

25. Ting-Peng, L., You, J.-J., \& Chih-Chung, L. (2010). A Resource-based Perspective on Information Technology and Firm Performance: A Meta Analysis. Industrial Management \& Data Systems, 110(8), 1138-1158.

26. Barney, J., \& Arikan, A. (2001). The resource-based view: Origins and implications. Handbook of Strategic Management, forthcoming.

27. Barney, J. B., \& Hesterly, W. S. (2015). Strategic management and competitive advantage: Concepts (5th ed.).

28. Russo, M. V., \& Fouts, P. A. (1997). Resource-Based Perspective on Corporate Environmental Performance and Profitability. The Academy of Management Journal, 40(3), 534-559. https://doi.org/10.2307/257052

29. Grant, R. M. (2016). Contemporary Strategy Analysis: Text and Cases Edition. West Sussex: John Wiley \& Sons.

30. Makadok, R. (2001). Toward a Synthesis of the Resource-based and Dynamic-capability Views of Rent Creation. Strategic Management Journal, 22(5), 387-401.

31. Pavia, J. L. (2002). Market Memo: Hospital Competition is Being Elevated to Clinical Performance. Health Care Strategic Management, 20(4), 12-15.

32. Kabene, S. M., Orchard, C., Howard, J. M., Soriano, M. A., \& Leduc, R. (2006). The Importance of Human Resource Management in Health Care: A Global Context. Human Resource for Health, 20(4), 20-37.

33. Bharadwaj, A. S. (2000). A Resource-Based Perspective on Information Technology Capability and Firm Performance: An Empirical Investigation. MIS Quarterly, 24(1), 169-196.
34. Santhanam, R., \& Hartono, E. (2003). Issues in Linking Information Technology Capability to Firm Performance. MIS Quarterly, 27(1), 125-153. https://doi.org/10.2307/30036521

35. Chae, H.-C., Koh, C. E., \& Prybutok, V. R. (2014). Information Technology Capability and Firm Performance: Contradictory Findings and Their Possible Causes. MIS Quarterly, 38(1), 305-326.

36. Felin, T., \& Hesterly, W. S. (2007). The Knowledge-Based View, Nested Heterogeneity, and New Value Creation: Philosophical Considerations on the Locus of Knowledge. The Academy of Management Review, 32(1), 195-218. https://doi.org/10.5465/amr.2007.23464020

37. Tseng, S.-M., \& Wu, C.-I. (2012). A Study on External Knowledge, Knowledge Management Capability and Corporate Performance. 2012 Annual SRII Global Conference (pp. 921-926). San Jose, CA: SRII Global Conference (SRII), 2012 Annual.

38. Porter, M. E., \& Teisberg, E. O. (2004). Redefining Competition in Healthcare. Hardvard Business Review, 82(6), 65-76.

39. Tseng, S.-M., \& Lee, P.-S. (2014). The Effect of Knowledge Management Capability and Dynamic Capability on Organizational Performance. Journal of Enterprise Information Management, 27(2), 158-179. https://doi.org/10.1108/JEIM-05-2012-0025

40. Hair, J. F., Hult, G. T., Ringle, C. M., \& Sarstedt, M. (2014). A Primer on Partial Least Squares Structural Equation Modeling (PLS-SEM). Thousand Oaks, California: SAGE Publications, Inc. 